\title{
Identifikasi Hubungan Kandungan Logam Berat dengan Nilai Suseptibilitas Magnetik pada Tanah Lapisan Atas di Kota Sawahlunto
}

\author{
Elga Sri Wahyuni*, Afdal \\ Laboratorium Fisika Bumi, Jurusan Fisika \\ Fakultas Matematika dan Ilmu Pengetahuan Alam Universitas Andalas \\ Kampus UNAND Limau Manis, Padang, 25163, Indonesia \\ *sriwahyunielga@gmail.com
}

\begin{abstract}
ABSTRAK
Telah dilakukan identifikasi kandungan logam berat menggunakan metode magnetik pada tanah lapisan atas pada empat lokasi di kota Sawahlunto yaitu pada daerah pertambangan, sekitar PLTU, daerah pertanian dan pusat kota Sawahlunto. Sampel tanah diambil sedalam $20 \mathrm{~cm}$ dari permukaan tanah, masing-masing 10 titik pada setiap lokasi. Pengukuran suseptibilitas magnetik menggunakan alat Bartington MS2 dengan sensor MS2B pada 15 arah berbeda. Hasil pengukuran menunjukkan bahwa sampel memiliki nilai suseptibilitas magnetik antara $12,9 \times 10^{-8}-98,4 \times 10^{-8} \mathrm{~m}^{3} / \mathrm{kg}$. Suseptibilitas magnetik dengan nilai lebih kecil daripada $150 \times 10^{-8} \mathrm{~m}^{3} / \mathrm{kg}$ termasuk kategori pencemaran tingkat rendah, namun di beberapa titik telah termasuk kedalam kategori pencemaran sedang. Untuk setiap lokasi diambil 5 sampel untuk ditentukan kandungan logamnya dengan X-Ray Flouroscence. Daerah yang tercemar logam berat paling banyak adalah daerah pusat kota Sawahlunto dengan kandungan rata-rata logam berat Cu (312 ppm), Zn (1612 ppm), Pb (226 ppm), As (108 ppm), Cr (136 ppm), Fe (123396 ppm). Daerah yang sedikit terkontaminasi logam berat yang telah melewati batas ambang dalam tanah yaitu daerah pertanian dengan logam As (32 ppm), Cr (22 ppm) dan Fe (71788 ppm). Logam berat yang telah melewati batas ambang untuk setiap lokasi pengambilan sampel adalah logam As, $\mathrm{Cr}$ dan Fe. Nilai suseptibilitas magnetik memiliki hubungan dengan konsentrasi logam berat walaupun dengan nilai koefisien korelasi yang kecil $(\mathrm{R}<0,5)$.

Kata kunci: suseptibilitas magnetik, logam berat, tanah lapisan atas
\end{abstract}

\section{ABSTRACT}

Heavy metal identification on top soil in mining areas, around power plant, agricultural areas and the town center of Sawahlunto have been carried out using magnetic method. Soil samples at 10 points on each location were taken at $20 \mathrm{~cm}$ depth from the soil surface. Magnetic susceptibility was measured using a Bartington MS2 magnetic susceptibility meter with MS2B sensor for 15 different directions. The results show that the samples have magnetic susceptibility value between $12.9 \times 10^{-8}-98.4 \times 10^{-8} \mathrm{~m}^{3} / \mathrm{kg}$. Magnetic susceptibility with the value loss than $150 \times 10^{-8} \mathrm{~m}^{3} / \mathrm{kg}$ includes the categories of the low level contamination, but at some points includes of medium pollution. Five samples from each location were selected to determine the metal contents using X-Ray Flourescence. The most contaminated area with heavy metals is downtown areas of Sawahlunto with the average value of Cu (312 ppm), Zn (1612 ppm), $\mathrm{Pb}$ (226 ppm), As (108 ppm), Cr (136 ppm). Moreover the less contaminated areas with heavy metals is agricultural areas wtih heavy metals that have crossed the threshold in the soil are As (32 ppm), Cr (22 ppm) and $\mathrm{Fe}$ (71788 ppm). Heavy metals that have passed the threshold for each of sampling sites are As, $\mathrm{Cr}$ and $\mathrm{Fe}$. The magnetic susceptibility has a weak relationship with heavy metal concentrations $(R<0,4)$. Keywords: magnetic susceptibility, heavy metals, topsoil

\section{PENDAHULUAN}

Pertambangan batubara di Sawahlunto telah beroperasi yaitu sejak zaman Hindia Belanda lebih dari 100 tahun yang lalu (Nawanir, 2003). Nilai Produk Domestik Regional Bruto (PDBR) dari hasil pertambangan mencapai nilai Rp 145,5 milyar (BPS kota Sawahlunto, 2008). Hal ini menunjukkan dampak positif pertambangan bagi perkembangan kota Sawahlunto. Hasil pertambangan batubara juga digunakan sebagai sumber energi kota Sawahlunto, yaitu Pembangkit Listrik Tenaga Uap (PLTU) yang terletak di daerah Talawi, Sawahlunto. Selain memberikan dampak positif, pertambangan batubara juga menimbulkan dampak negatif yang meresahkan masyarakat. Debu hasil pembakaran PLTU misalnya menimbulkan polusi udara yang cukup mengkhawatirkan. Polusi udara berdampak kepada kesehatan pernafasan masyarakat sekitar, apalagi lokasi PLTU terletak di sekitar lingkungan padat penduduk. Selain pencemaran udara, pertambangan juga menimbulkan polusi tanah. Partikulat dari debu pertambangan yang terbawa oleh angin dapat terdeposisi pada tanah serta menempel pada daun 
dan bangunan (Yuliatri dkk., 2013). Dalam tanah yang tercemar terdapat logam berat yang berbahaya bagi kehidupan masyarakat.

Logam berat yang terkandung dalam suatu bahan dapat ditentukan dengan metode geokimia menggunakan alat Atomic Absorption Spectroscopy (AAS) dan X-Ray Flouroscence (XRF). Grzebisz dkk., (2002) melakukan penelitian kandungan logam berat di tanah perkotaan Polandia menggunakan analisis geokimia dan menemukan kandungan logam berat yang tinggi. Namun untuk mengetahui sebaran logam di permukaan tanah, metode ini kurang efektif dan efisien untuk digunakan. Hal ini dikarenakan metode ini melibatkan sampel yang cukup banyak sehingga memerlukan waktu yang lama dan biaya yang mahal.

Salah satu metode alternatif untuk mengatasi hal tersebut adalah metode magnetik. Metode magnetik telah sukses digunakan untuk mendeteksi tingkat polusi tanah (Wang dkk., 2015). Partikel magnetik yang diidentifikasi dengan nilai suseptibilitas magnetik yang tinggi terdapat pada tanah permukaan ditemukan di daerah perkotaan (Lu dkk., 2010), daerah pertambangan, industri semen, daerah pembakaran sampah dan pabrik baja.

Beberapa hasil penelitian mengindikasikan nilai suseptibilitas magnetik pada tanah permukaan provinsi Kocaeli Turki dengan hasil nilai suseptibilitas magnetik berpengaruh pada konsentrasi logam berat pada tanah lapisan atas (Canbay (2010). Adanya hubungan antara kandungan logam berat dengan nilai suseptibilitas magnetik yang tinggi pada tanah permukaan di daerah Jerman (Rachwal dkk., 2017). Hal ini menunjukkan bahwa nilai suseptibilitas magnetik dapat digunakan sebagai indikator adanya kandungan logam berat pada tanah lapisan atas.

Mindasari (2007) telah melakukan penelitian mengenai dampak kegiatan pertambangan batubara di kota Sawahlunto terhadap kualitas air sungai Ombilin. Penelitian tersebut mengindikasikan kegiatan pertambangan menyebabkan perubahan fisik air di sepanjang sungai Ombilin. Penelitian pada tanah lapisan atas di kota Sawahlunto belum pernah dilakukan sebelumnya, maka penulis melakukan penelitian untuk mengidentifikasi hubungan kandungan logam berat dengan nilai suseptibilitas magnetik pada tanah lapisan atas di kota Sawahlunto. Tujuan dari penelitian ini adalah untuk mengidentifikasi sebaran logam berat dan suseptibilitas magnetik yang berada pada tanah permukaan di kota Sawahlunto. Manfaat dari penelitian ini adalah dapat mengetahui tingkat dan sebaran logam berat dan suseptibilitas magnetik pada tanah permukaan di kota Sawahlunto.

\section{METODE}

Penelitian dilakukan di Laboratorium Fisika Bumi Jurusan Fisika Universitas Andalas dan Laboratorium Instrumentasi Jurusan Kimia Universitas Negeri Padang. Penelitian dilakukan dari April sampai Desember 2017. Lokasi yang menjadi objek penelitian adalah tanah permukaan di sekitar daerah pertambangan batubara, PLTU, pusat kota dan daerah pertanian di Kota Sawahlunto.

Sampel yang diambil berupa tanah bagian atas pada kedalaman $20 \mathrm{~cm}$ menggunakan pipa PVC sebanyak lebih kurang $50 \mathrm{~g}$ di 40 titik yang tersebar di sekitar pertambangan batubara, PLTU, daerah pertanian dan pusat kota Sawahlunto seperti yang terlihat pada Gambar 1 sampai Gambar 4. Sampel yang telah diambil kemudian dikeringkan, diayak dan dimasukkan ke dalam sampel holder. Pengukuran nilai suseptibilitas magnetik menggunakan Bartington MS2 dengan sensor MS2B dilakukan di Laboratorium Fisika Bumi, Universitas Andalas. Sampel tanah sebanyak 12 g yang telah dimasukkan ke dalam sampel holder diukur nilai suseptibilitas magnetiknya. Pengukuran dilakukan pada 15 arah. Data tersebut kemudian diolah menggunakan program MATLAB 2012a untuk mendapatkan nilai suseptibilitas magnetik yang tunggal. Pengukuran kandungan logam berat dilakukan di Laboratorium Instrumentasi Jurusan Kimia, Universitas Negeri Padang menggunakan XRF. 


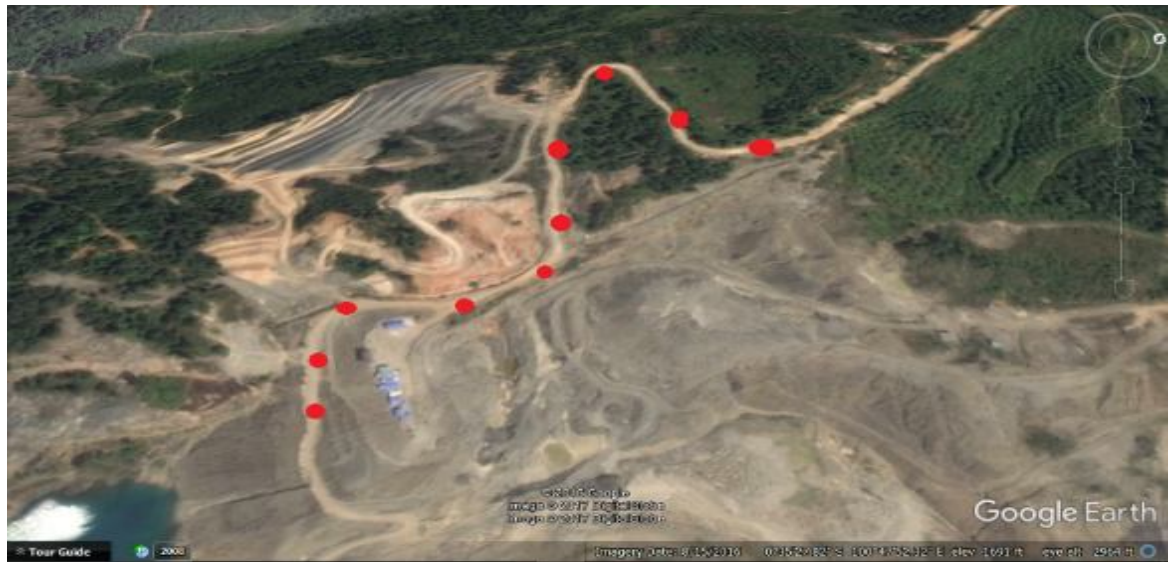

Gambar 1 Titik-titik pengambilan sampel di sekitar pertambangan batubara

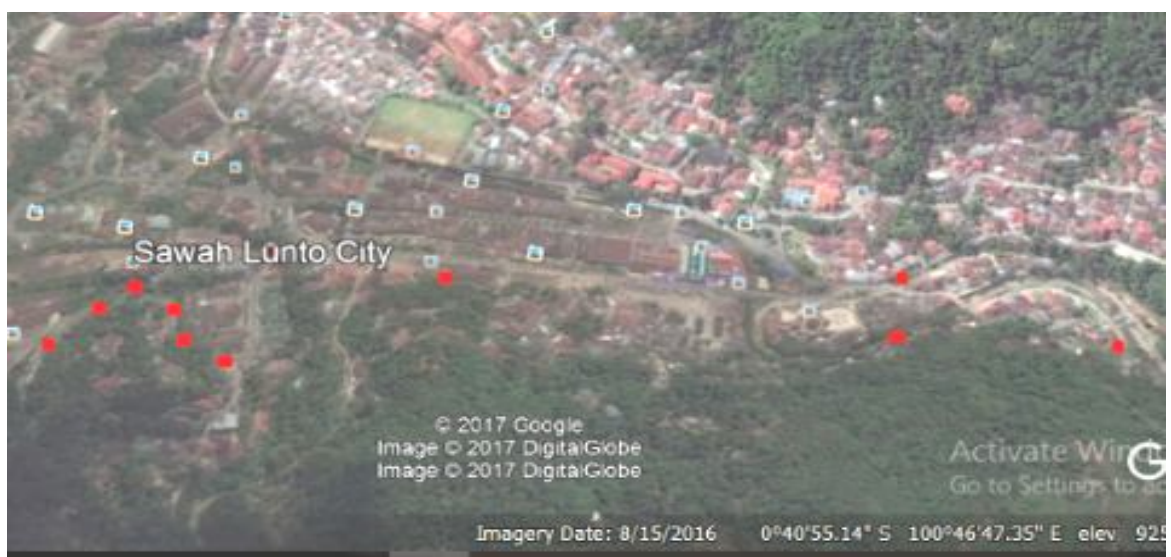

Gambar 2 Titik-titik pengambilan sampel di pusat kota Sawahlunto

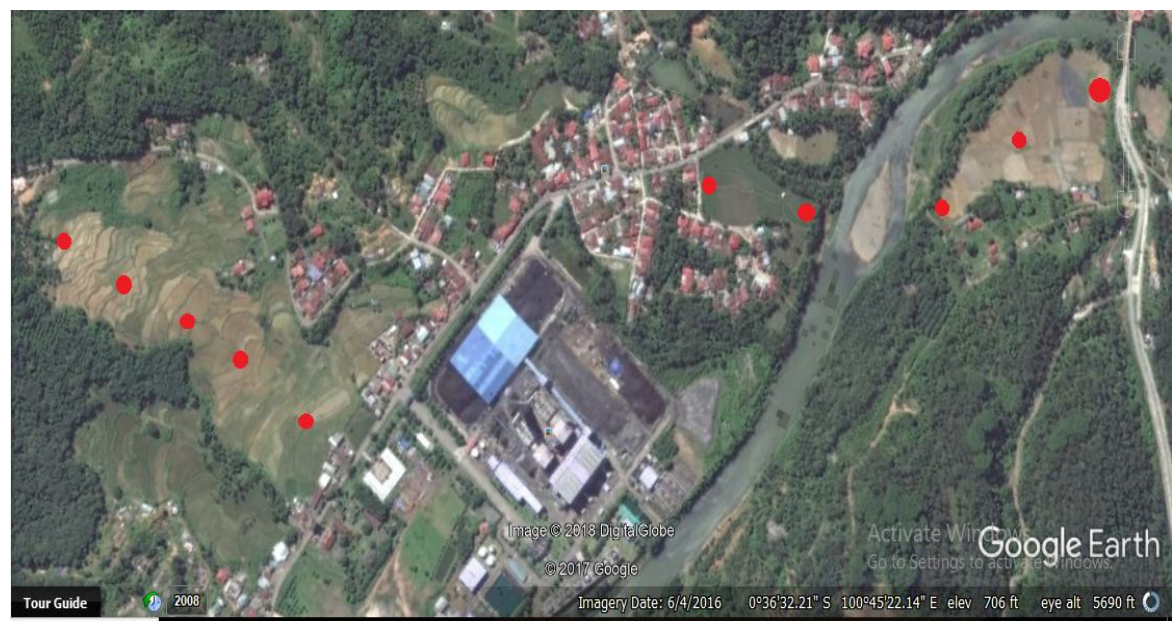

Gambar 3 Titik-titik pengambilan sampel di sekitar PLTU 


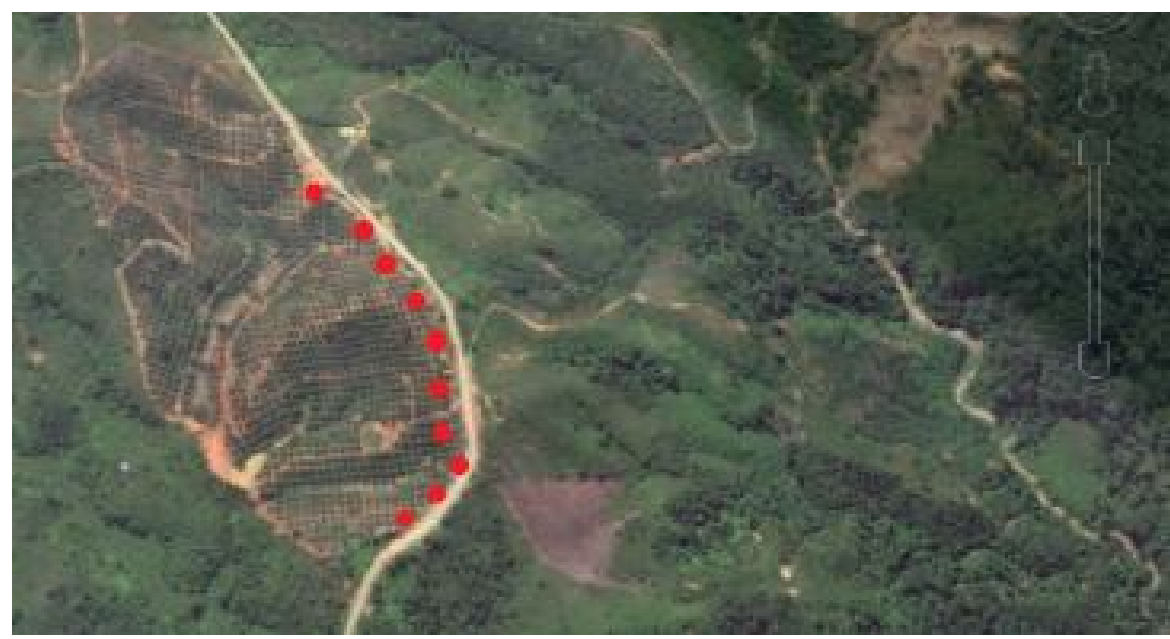

Gambar 4 Titik-titik pengambilan sampel di daerah pertanian

\section{HASIL DAN DISKUSI}

\subsection{Suseptibilitas Magnetik}

Nilai rata-rata suseptibilitas magnetik berada pada nilai $12,9 \times 10^{-8}-98,4 \times 10^{-8} \mathrm{~m}^{3} / \mathrm{kg}$. Menurut Evan dan Heller (2003) dalam Yuliatri dkk (2013), nilai suseptibilitas magnetik dengan nilai $<150 \times 10^{-8} \mathrm{~m}^{3} / \mathrm{kg}$ merupakan termasuk kategori pencemaran rendah. Namun di beberapa titik telah melewati dari batas tersebut, yaitu pada sampel K4 di daerah pusat kota dengan nilai $259,9 \times 10^{-8} \mathrm{~m}^{3} / \mathrm{kg}$. Kemudian pada sampel PL6 dan PL8 di daerah PLTU dengan nilai $257,9 \times 10^{-8} \mathrm{~m}^{3} / \mathrm{kg}$ dan $174,9 \times 10^{-8} \mathrm{~m}^{3} / \mathrm{kg}$.

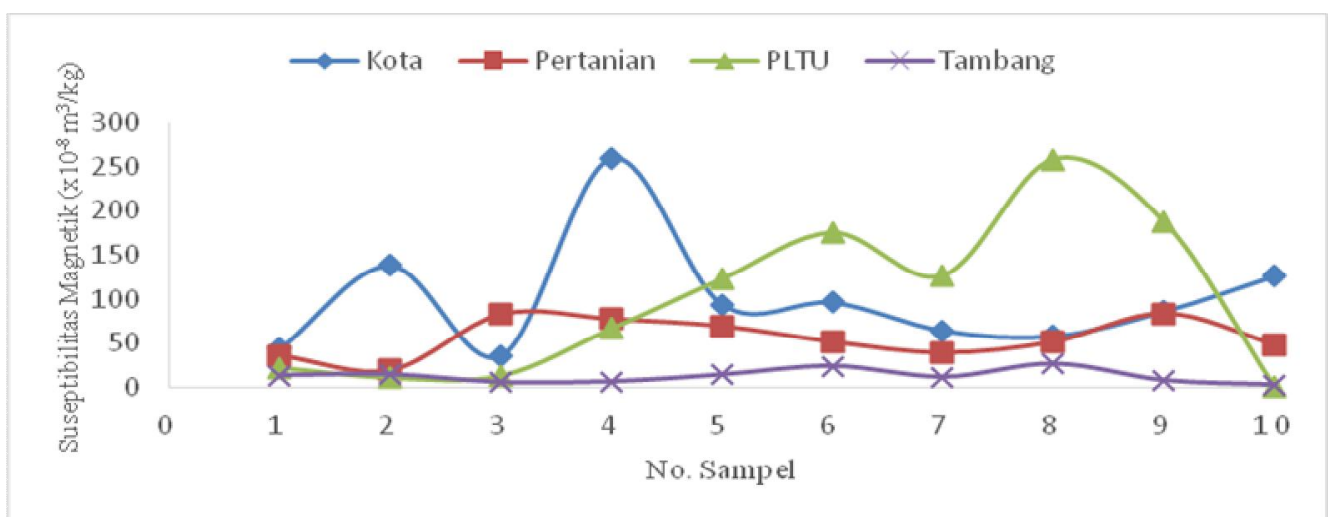

Gambar 5 Grafik nilai suseptibilitas magnetik pada masing-masing lokasi

Nilai suseptibilitas magnetik di daerah pertambangan lebih rendah dibandingkan dengan daerah yang lainnya (Gambar 5). Hal ini dikarenakan, sumber pencemar di daerah pertambangan hanya berasal dari pertambangan saja sedangkan di daerah lainnya, terdapat sumber pencemar lainnya yang mempengaruhi kenaikan nilai suseptibilitas magnetik. Menurut Nawanir (2003), dampak pertambangan batubara yang sesungguhnya adalah mengubah fungsi lahan yang awalnya hutan menjadi daerah pertambangan, sedangkan kandungan dari batubara murni tidak membahayakan lingkungan, yang terlihat dari nilai suseptibilitas magnetiknya yang rendah. Selain itu, tanah yang diambil di daerah pertambangan bisa jadi bukan termasuk tanah lapisan atas, karena telah terjadi penggalian pertambangan. Daerah pertanian memiliki nilai suseptibilitas yang lebih tinggi dari daerah pertambangan. Hal ini dikarenakan pemberian pupuk pada tumbuhan juga mempengaruhi nilai suseptibilitas magnetik (Andyana dkk, 2016). Daerah PLTU memiliki nilai suseptibilitas magnetik yang cenderung lebih tinggi dari daerah pertambangan dan pertanian. Hal ini dikarenakan abu pembakaran batubara di PLTU terbang dan mengendap di tanah lapisan atas di daerah sekitar PLTU. Debu dari PLTU menyumbang polusi yang besar bagi lingkungan sekitar. Nilai maksimum suseptibilitas magnetik terletak di daerah pusat kota. Rata-rata di daerah ini memiliki nilai suseptibilitas magnetik yang lebih besar 
dari daerah yang lain. Hal ini dikarenakan daerah ini lalu lintas kendaraan ramai dan banyaknya limbah rumah tangga yang memungkinkan meningkatkan kadar suseptibilitas magnetik dalam tanah.

\subsection{Konsentrasi Logam Berat}

Logam yang telah melewati batas ambang di daerah PLTU, yaitu logam $\mathrm{Cu}$, As dan $\mathrm{Cr}$. dengan rata-rata nilai konsentrasi logam berat masing-masingnya sebesar 110, 30 dan $150 \mathrm{ppm}$. Logam yang belum melewati batas ambang yaitu $\mathrm{Mn}, \mathrm{Ni}, \mathrm{Zn}$ dan $\mathrm{Pb}$. Jenis logam berat yang telah melewati batas ambang di daerah PLTU sama dengan daerah pertambangan. Hal ini menunjukkan jika sumber pencemarnya sama, yaitu batubara.

Tabel 1 Konsentrasi logam berat pada masing-masing lokasi

\begin{tabular}{|c|c|c|c|c|c|c|c|c|}
\hline \multirow{2}{*}{ Lokasi } & \multirow{2}{*}{ Sampel } & \multicolumn{7}{|c|}{ Konsentrasi Logam Berat (ppm) } \\
\hline & & Mn & $\mathbf{N i}$ & $\mathbf{C u}$ & $\mathbf{Z n}$ & $\mathbf{P b}$ & As & $\mathbf{C r}$ \\
\hline \multirow[t]{6}{*}{ Tambang (T) } & T1 & 0 & 30 & 510 & 600 & 280 & 10 & 160 \\
\hline & T3 & 0 & 0 & 320 & 40 & 140 & 30 & 190 \\
\hline & T6 & 0 & 0 & 0 & 50 & 30 & 20 & 170 \\
\hline & T8 & 50 & 60 & 80 & 240 & 60 & 30 & 160 \\
\hline & T10 & 1390 & 80 & 110 & 250 & 70 & 0 & 180 \\
\hline & Rata-rata & 288 & 34 & 204 & 236 & 116 & 18 & 172 \\
\hline \multirow{6}{*}{ PLTU (PL) } & PL1 & 850 & 60 & 80 & 220 & 60 & 20 & 150 \\
\hline & PL4 & 400 & 110 & 110 & 290 & 100 & 30 & 220 \\
\hline & PL6 & 790 & 30 & 130 & 290 & 50 & 40 & 90 \\
\hline & PL8 & 280 & 40 & 90 & 260 & 80 & 30 & 140 \\
\hline & PL10 & 1060 & 50 & 140 & 370 & 80 & 30 & 150 \\
\hline & Rata-rata & 676 & 58 & 110 & 286 & 74 & 30 & 150 \\
\hline \multirow[t]{6}{*}{ Kota $(\mathrm{K})$} & K1 & 1150 & 30 & 360 & 460 & 130 & 110 & 180 \\
\hline & K3 & 1190 & 10 & 220 & 580 & 240 & 190 & 110 \\
\hline & K4 & 3470 & 0 & 280 & 850 & 240 & 120 & 70 \\
\hline & K7 & 1290 & 40 & 290 & 400 & 160 & 90 & 190 \\
\hline & K10 & 3010 & 30 & 410 & 5770 & 360 & 30 & 130 \\
\hline & Rata-rata & 2022 & 22 & 312 & 1612 & 226 & 108 & 136 \\
\hline \multirow[t]{6}{*}{ Pertanian (P) } & $\mathrm{P} 2$ & 80 & 10 & 80 & 270 & 60 & 40 & 60 \\
\hline & P4 & 120 & 0 & 0 & 160 & 50 & 30 & 50 \\
\hline & P6 & 180 & 0 & 0 & 190 & 50 & 30 & 0 \\
\hline & P7 & 120 & 0 & 0 & 270 & 70 & 40 & 0 \\
\hline & P9 & 260 & 0 & 0 & 140 & 30 & 20 & 0 \\
\hline & Rata-rata & 152 & 2 & 16 & 206 & 52 & 32 & 22 \\
\hline \multicolumn{2}{|c|}{ Rata-rata Keseluruhan } & 784,5 & 29 & 160,5 & 585 & 117 & 47 & 120 \\
\hline \multicolumn{2}{|l|}{ Maksimum } & 3470 & 110 & 510 & 5770 & 360 & 190 & 220 \\
\hline \multicolumn{2}{|c|}{ Minimum } & 0 & 0 & 0 & 40 & 30 & 0 & 0 \\
\hline \multicolumn{2}{|c|}{ Batas Ambang dalam Tanah } & $4000^{*}$ & $1000^{*}$ & $100 *$ & $300 *$ & $200 *$ & $4 *$ & $2,5 * *$ \\
\hline
\end{tabular}

*Pickering (1980) dalam Erfandi dan Juarsah (2014)

* Ministry of State for Population and Environment of Indonesia and Dalhousie University, Canada (1992) dalam Erfandi dan Juarsah (2014)

Logam-logam berat yang telah melebihi batas ambang dalam tanah di daerah pusat kota Sawahlunto adalah logam $\mathrm{Cu}, \mathrm{Zn}, \mathrm{Pb}$, As dan $\mathrm{Cr}$. Keberadaan logam berat yang paling banyak melewati batas ambang dalam tanah disebabkan oleh karena emisi gas buangan kendaraan bermotor dan limbah rumah tangga sehingga membuat konsentrasi logam beratnya tinggi. Semakin padat lalu lintas mengakibatkan keberadaan logam berat semakin tinggi (Yulius dan Afdal, 2014).

Daerah pertanian memiliki kandungan logam berat yang lebih kecil dibandingkan dengan lokasi yang lainnya. Jenis logam yang melewati batas ambang dalam tanah pun hanya 2 
dari 7 logam berat. Logam berat yang telah melewati ambang batas pada lokasi ini yaitu logam As dengan konsentrasi rata-rata logam berat sebesar $32 \mathrm{ppm}$, logam berat $\mathrm{Cr}$ dengan nilai ratarata logam berat sebesar $22 \mathrm{ppm}$. Hal ini berarti, jumlah polusi di daerah pertanian lebih sedikit dari lokasi yang lain.

\subsection{Hubungan Nilai Suseptibilitas Magnetik dengan Kandungan Logam Berat}

Hubungan nilai suseptibilitas magnetik dengan konsentrasi logam berat dapat dilihat pada Gambar 6 berikut. Nilai suseptibilitas magnetik memiliki hubungan dengan konsentrasi logam berat. Dapat dilihat pada grafik nilai koefisien korelasi logam $\mathrm{Mn}, \mathrm{Zn}, \mathrm{Pb}, \mathrm{As}$ dan $\mathrm{Pb}$ memiliki nilai positif, sebesar 0,$207 ; 0,253 ; 0,077 ; 0,423$; dan $0 ; 136$. Nilai korelasi yang kecil mengindikansikan hubungan yang lemah antara nilai suseptibilitas magnetik dengan konsentrasi logam berat. Logam berat $\mathrm{Ni}, \mathrm{Cu}$ dan $\mathrm{Cr}$ memiliki nilai koefisien korelasi yang negatif yang berarti nilai suseptibilitas magnetik berbanding terbalik dengan konsentrasi logam berat $\mathrm{Ni}, \mathrm{Cu}$ dan Cr. Nilai konsentrasi logam berat cenderung meningkat seiring dengan meningkatnya nilai suseptibilitas magnetik. Secara keseluruhan nilai suseptibilitas magnetik dapat mendeteksi adanya kandungan logam berat pada tanah lapisan atas.
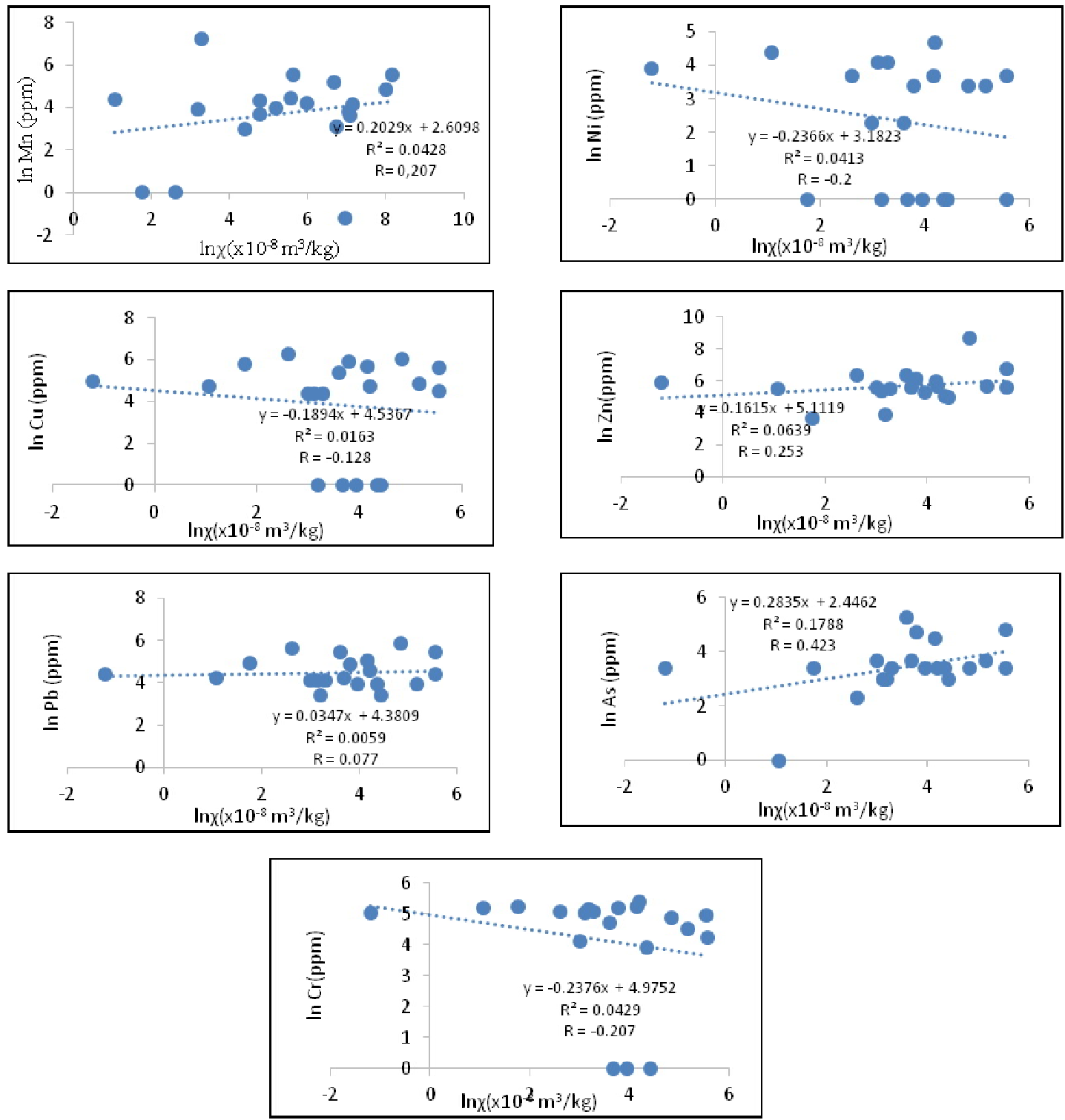

Gambar 6 Plot data dan persamaan regresi linear konsentrasi logam berat terhadap suseptibilitas magnetik 


\section{KESIMPULAN}

Nilai suseptibilitas magnetik memiliki rentang nilai dari $0,3 \times 10^{-8} \mathrm{~m}^{3} / \mathrm{kg}$ (PL10) $259,9 \times 10^{-8} \mathrm{~m}^{3} / \mathrm{kg}$ (K4) dan nilai rata-rata di setiap lokasi pengambilan sampel di kota Sawahlunto adalah $12,9-98,4 \times 10^{-8} \mathrm{~m}^{3} / \mathrm{kg}$. Dari nilai rata-rata suseptibilitas magnetik pencemaran di kota Sawahlunto masih termasuk kategori pencemaran rendah, namun di beberapa titik telah termasuk kedalam kategori pencemaran sedang. Sampel mengandung logam-logam berat seperti $\mathrm{As}, \mathrm{Cu}, \mathrm{Cr}, \mathrm{Pb}, \mathrm{Mn}$, $\mathrm{Ni}$ dan $\mathrm{Zn}$ yang merupakan logam yang berasal dari debu batubara, aktivitas kendaraan bermotor dan limbah kegiatan industri. Nilai koefisien korelasi suseptibilitas magnetik dengan konsentrasi logam berat berkisar antara -0,128 hingga 0,423 . Dari 7 logam berat, hanya 3 logam berat yang memiliki koefisien korelasi yang negatif. Hal ini menandakan nilai suseptibilitas magnetik berkontribusi terhadap konsentrasi logam berat walaupun dengan nilai koefisien korelasi yang kecil.

\section{DAFTAR PUSTAKA}

Andyana, D. R., Zulaikah, S., Sutrisno, 2016, Pengaruh Penyiraman Fe terhadap Suseptibilitas Magnetik Tanah pada Media Tanaman Tomat dan Implikasinya pada Tinggi Batang, Serta Lebar, Panjang, dan Banyak Daun, Seminar Nasional Jurusan Fisika FMIPA UM, ISBN 978-602-71279-1-9

Badan Pusat Statistik, 2008, Gambaran Umum Kota Sawahlunto, Kota Sawahlunto, Sumatera Barat.

Canbay, M., 2010, Investigation of the Relation Between Heavy Metal Contamination of Soil and Its Magnetic Sesceptibility, Vol. 5(5), International Journal of Physical Sciences, hal. 393-400.

Erfandi, D. dan Juarsah, I., 2014, Konservasi Tanah Menghadapi Perubahan Iklim, Badan Penelitian dan Pengembangan Pertanian, Jakarta.

Grzebisz, W., Ciesla, L., Komisarek, J. dan Potarzycki, J., 2002, Geochemical Assessment of Heavy Metals Pollution of Urban Soils, Polish Journal of Environmental Studies, Vol. 11, No. 5, hal. 493-499.

Lu, S., Wang, H. dan Guo, J., 2010, Magnetic Response of Heavy Metals Pollution in Urban Soils: Magetic Proxy Parameters as an Indicator of Heavy Metals Pollution, World Congress of Soil Science Soil Solutions for a Changing World, Zhejiang University, China.

Mindasari, L., 2007, Dampak kegiatan Pertambangan Batubara PT. Tambang Batubara Bukit Asam (PT. BA) (PERSERO) TBK-Unit Produksi Ombilin (UPO) dan Tambang Batubara Tanpa Izin (PETI) terhadap Kualitas Air Sungai Ombilin Sawahlunto, Skripsi, Institut Pertanian Bogor, Bogor.

Nawanir, H., 2003, Studi Pengembangan Ekonomi dan Keruangan Kota Sawahlunto Pascatambang, Tesis, Universitas Diponegoro, Semarang.

Rachwal, M., Kardel, K., Magiera, T. Bens, O., 2017, Aplication of Magnetic Susceptibility in Assessment of Heavy Metal Contamination of Saxonian Soil (Germany) Caused by Industrial Dust Deposition, Geoderma, Vol. 295, hal.10-21

Wang, B., Xia, D., Yu, Y., Jia., Nie, Y. dan Wang, X., 2015, Detecting the Sensitivity of Magnetic Response of Different Pollution Sources A Case Study from Typical Mining Cities In Northwestern China, Environmental Pollution, hal. 288-298

Yuliatri, W., Mahrizal, Mufit, F., 2013, Penentuan Tingkat Polusi Udara Akibat Kendaraan Bermotor Menggunakan Metoda Suseptibilitas Magnetik di Kota Padang, Pillar of Physics, Vol. 1, hal. 121-128.

Yulius, U. dan Afdal., 2014, Identifikasi Sebaran Logam Berat pada Tanah Lapisan Atas dan Hubungannya dengan Suseptibilitas Magnetik di Beberapa Ruas Jalan Disekitar Pelabuhan Teluk Bayur Padang, Jurnal Fisika UNAND, Vol. 3, No.4. 